\title{
КОМПАРАТИВНА АНАЛИЗА ПОРОДИЧНЕ ПЕДАГОГИЈЕ У СТУДИЈСКИМ ПРОГРАМИМА ПЕДАГОГИЈЕ ФИЛОЗОФСКИХ ФАКУЛТЕТА У СРБИЈИ И ОКРУЖЕЫУ ${ }^{12}$
}

\author{
Марина Матејевић ${ }^{3}$, Марија Ђорђевић \\ Универзитет у Нишу, Филозофски факултет, Департман за педагогију
}

\begin{abstract}
Ancmpaкm: Породична педагогија као предмет у оквиру студијских програма педагогије присутна је у последњој деценији XX века, најпре као изборни предмет, а тек је почетком XXI породична педагогија сврстана у групу обавезних предмета. У раду је представљен развој породичне педагогије код нас. Истраживање је спроведено у намери да испитамо како је област породичне педагогије на студијама педагогије присутна и позиционирана на филозофским факултетима у Србији и окружењу. Коришћена је техника анализа садржаја доступних програмских докумената и силабуса. Основне јединице анализе биле су: студијски програм, година студија и семестар, назив предмета, статус предмета и број ESPB кредита. Резултати компаративне анализе показују да су на свим проучаваним филозофским факултетима присутни садржаји из области породичне педагогије, притом свуда у статусу обавезних предмета у студијским програмима педагогије. Разлике се примећују нарочито у години и семестру у коме се слуша и броју ESPB кредита. Анализом смо покушали да укажемо на могућност уношења одређених промена у начину реализације, пре свега у броју ESPB кредита, али и на евентуално ширење и унапређивање предмета из области породичне педагогије.
\end{abstract}

Кључне речи: породична педагогија, назив предмета, статус предмета, студијски програм

\section{Увод}

Интересовања за породицу и проблеме васпитања у породици појавила су се још у делима античких филозофа пре наше ере. Мисли о породичном васпитању у делима наших педагога, присутне су крајем XIX и почетком XX века.

\footnotetext{
${ }^{1}$ Рад је настао као резултат рада на пројекту број 183/1-16-8-01, под називом Унайређивағе $u$ осавременаване основних академских сйудија иеедагогије, финансираном од стране Филозофског факултета у Нишу.

${ }^{2}$ Ово истраживање финансијски је подржало Министарство просвете, науке и технолошког развоја Републике Србије.

${ }^{3}$ marina.matejevic@filfak.ni.ac.rs
} 
Оснивањем катедре за педагогију на Великој школи у Београду 1892. године, постављењем Војислава Бакића за професора педагогије, створене су могућности за развој педагошке науке, а тиме и породичне педагогије као педагошке дисциплине. Ипак, Породична педагогија као предмет у оквиру студијских програма педагогије присутна је тек након једног века, у последњој деценији $\mathrm{XX}$ века, најпре као изборни предмет, тек почетком XXI породична педагогија је сврстана у групу обавезних предмета.

\section{1. Развој идеја о породичном васпитању и Породичне педагогије као педагошке дисциплине}

Идеје о васпитној функцији породице и значају образовања родитеља за обављање ове значајне улоге, биле су присутне у делима наших педагога крајем XIX и почетком XX века. Тако је Војислав Бакић (1847-1929), писао о васпитању у породици у својој књизи „Поуке о васпитању деце у родитељској кући“. Бакић је истицао значај мајке за васпитање деце и указивао на потребу педагошког образовања родитеља. Сматрао је да је најјача је и најтрајнија љубав матере према своме детету, а она је најглавнији чинилац при домаћем васпитању (Bakić, 1901: 7). Док мајка васпитава дете својом љубављу и примером, отац васпитава више својим ауторитетом и својом доследношћу, сматра Бакић. Такође је истицао родитељску слогу, подједнако поступање према деци и доследност. Сматрао је да је отац старешина породице, и да је одговоран за рад и ред у породичном животу. Због тога је неопходно да отац буде ауторитативан и тактичан при васпитању деце, сматрао је. Може се констатовати да Бакићево схватање родитељског ауторитета одржава односе који су владали у српској патријархалној породици. Он је чак и критиковао градске породице и породице интелектуалаца у Србији у којима је дошло до напуштања старих и успостављања нових породичних односа. Залагао за патријархално конзервативни стил у васпитању родитеља и ова његова схватања свакако не одражавају прогресивни већ конзервативни дух у педагогији.

Значајно је поменти у овом периоду и схватања Јована Миодраговића (1854-1926), који је писао о породици као значајном фактору васпитања као и о потреби педагошког образовања родитеља. У свом делу „Народна педаго-

гија у Срба или како наш народ подиже пород свој“, Миодраговић наводи да је породично васпитање темељ даљег развитка човека и основа друштвеног васпитања. Он сматра да је породица извор сваког добра и благослова, огњиште јавне безбедности, народне снаге и свих врлина, и да нема чвршће основе за ону зграду што се зове народно образовање од породице (Miodragović, 1914).

Значајем породичног васпитања бавио се и наш педагог Сретен Аџић. Сматрао је да је брижљивим васпитањем у породици могуће сваког појединца усавршити. Зато је он упозоравао родитеље да обрате пажњу чему уче своју децу, какве им примере дају, јер породично васпитање представља темељ свег каснијег васпитања. Супротстављајући се васпитању које полази од слободног 
развоја деце, Аџић се залаже за златну средину у васпитању, где родитељи не помажу деци ни сувише много ни сувише мало, већ само колико је потребно. Тако он каже ,пустите дете да само расте као дрво у шуми, без такорећи икакве ваше помоћи - погрешно је, али је исто тако погрешна и претерана помоћ која разнежи, размази и убије свако самопоуздање... Родитељска љубав је што и сунце. Ако сувише пржи оно све спржи. Ако га нема биљка клоне од хладноће. Само на благој равномерној сунчаној топлоти добро успевају нежне биљчице. А под небом нема нежнијег рашћа од детета“ (Milošević, 1999: 467). За разлику од Бакићевог конзерватизма Аџић има у свом ставу према васпитању деце, пуно благости и љубави. Зато он каже „О, кад би знали и учитељи и родитељи колико отрова и горчине сипљу у дечији живот и дечју душу својом претераном строгошћу, својим надувеним деспотством, својим вечитим кажњавањем - они би се ужаснули од чуда и никада више не би тога чинили. Па и сама чемерна биљка морала би постати горка, кад би се непрестано само чемером заливала!... Казна увек понижава, гради од образа - ђон, а од срца камен, па ма се она састојала само у прекорном погледу... (Milošević, 1999: 468). Схватања Аџића о кажњавању су веома напредна и указују на његов веома хуман однос према детету, који се изражава кроз поштовање личности детета.

Војислав Младеновић (1884-1964) такође је истицао значај породице и родитеља за васпитање деце. По њему породица је најужи, али најприроднији и првобитни облик заједнице (Mladenović, 1922). Младеновић је критиковао тадашњу породицу, због начина организације живота, јер су родитељи били приморавани да раде у фабрикама и нису имали довољно времена да брину о својој деци. Због тога, је сматрао да породици треба помоћи, јер су родитељи незаменљив фактор у васпитању деце.

Наш познати педагог Вићентије Ракић (1881-1969) такође је истицао значај породице за формирање личности. По Ракићевом мишљењу породица је први и основни фактор социјалног развоја и живота, јер прве и најбоље социјалне навике дете преживљава у породици, а оне су основ за његово даље социјално развијање (Теšić, 1981).

Иако између напред поменутих педагога постоје разлике у сагледавању породичног васпитања, заједничко им је свакако то што сви они сматрају да су родитељи незамењив фактор у васпитању деце и да им је потребна подршка у припремању за ову врло одговорну улогу.

У периоду после Другог светског рата, периоду изградње новог социјалистичког друштва, проучавање породице и њене васпитне функције прошло је кроз три фазе (Pediček, 1982; Stanojlović, 1990): од 1945-1950. г.; од 1950-1970. г., и од 1970. до 1982. По нашем мишљењу од краја осамдесетих и почетка деведесетих година почиње једна нова, четврта фаза у проучавању породичног васпитања.

Прва послератна фаза, 1945-1950 године, карактерише се настојањима да се створи нова педагошка наука, у складу са социјалистичким друштвеним поретком. Наша педагогија је у овом периоду углавном прихватала и подржавала приступе и схватања совјетске педагогије о социјалистичком васпитању. 
У Совјетској Русији се развијала педагошка наука која није била наклоњена породици и неговању васпитне функције породице. Након октобарске револуције, совјетске власти су сматрале да треба уништити породицу као тековину буржоаског друштва. Донели су низ прописа, почев од увођења слободе у разводу бракова 1917. године, а потом су 1926. године укинули и обавезе склапања и развода брака. У складу са тим промовисано је друштвено васпитање, на рачун васпитне функције породице, чак је било идеја да децу треба васпитавати у посебним ,дечјим градовима”, како би били што више удаљени од родитеља, како би се смањио васпитни утицај породице. Због овакве законске регулативе, у Совјетској Русији се појавио велики број деце без родитељског старања, са поремећајима у понашању, преко двадест милиона деце којој је требало преваспитање у васпитним заводима. Совјетске власти биле принуђене да врате законске обавезе које су се односиле на склапање и развод брака 1944. године, што је значило на неки начин и признавање значаја породице у остваривању њене васпитне функције (Stanojlović, 1990).

Подаци који указују на однос совјетских власти према породици су веома значајни за разумевање односа који је постајао према породичној педагогији у оквиру наше педагошке теорије, која је била под веома снажним утицајем совјетске педагогије. Поред ових неповољних утицаја, због сагледавања породице као буржоаске тековине, присутан је још један неповољни контекст који се односио на теоријски и методолошки приступ у сагледавању проблема васпитања. У овом периоду совјетска педагогија се развијала под утицајем социјалног приступа у васпитању, те је и код нас било прихваћено схватање о непотребности и нефункционалности породице за социјалистичко друштво, сматрало се да одређене друштвене установе могу заменити породицу. Породица је могла бити извор негативног утицаја родитеља који нису били довољно политички активни у спровођењу партијских директива. Због тога није постојала потреба за проучавањем проблема породичног васпитања, јер су васпитни поступци родитеља и уопште односи између родитеља и деце, били у сенци институционалног, друштвено ангажованог васпитања. Разлог због кога ова проблематика није проучавана је свакако и тај што дедуктивни методолошки приступ није пружао могућности за емпиријска истраживања, већ само за извикавање комунистичких парола из којих су извлачена руководства за васпитни рад.

Друга фаза 1950-1970. године, садржи два ужа, специфична периода (1950-1960. године и 1960-1970. године). У првој фази почиње да се испољава критички однос према совјетској педагогији, што је наравно било условљено политичким раскидом са Совјетском Русијом. То је позитивно утицало на развој научне педагогије и развој схватања да породицу и родитеље у васпитању деце не могу заменити никакве друштвене институције. У овом периоду је, после превођења руских педагогија, објављен први наш уџбеник педагогије, у редакцији Стјепана Патакија, у коме се у оквиру поглавља Ваннаставни и ваншколски васпитни рад нашао поднаслов Породично васпитање (Pataki, 1950). Поново почиње да се истиче значај родитеља у васпитању деце и развија интересовање за проблеме породице и њене васпитне функције, са посебним 
нагласком на сарадњу породице и школе и других педагошких институција. Интересовања за проучавање породице се појачавају, тако да се у другој етапи (1960-1970. године) почињу да организују емпиријска истраживања, као и саветовања о породици и њеној васпитној улози, мада ово подручје још увек није адекватно заступљено у педагошкој литератури. У уџбенику Педагогије у редакцији Крнете и сарадника (Krneta i sar., 1965) у делу који се односи на педагошке дисциплине наводи се породична педагогија као педагошка дисациплина. Према овим ауторима породична педагогија се бави проблемима васпитања деце у породици, а посебно условима и факторима породичног васпитања, садржајима, методама и средствима породичног васпитања, проучавањем односа између породице и школе и породице и ваншколских педагошких институција. Такође се наводи образовање родитеља као значајан задатак породичне педагогије (Krneta i sar., 1965) .

Овај период такође карактерише повећано интересовање других наука за проблеме породичног васпитања, као што су између осталих психологија, и социологија. ,Тако је педагошка теорија изгубила конструктивну улогу у оснивању и обликовању теорије и праксе породичног васпитања“ (Stanojlović, 1992: 42). Овакав положај педагогије у односу на сродне науке био је условљен неизграђеношћу њене методологије, што је свакако имало утицаја да педагогија не буде довољно ангажована у истраживању проблема везаних за породицу и односе између родитеља и деце.

За трећи период који траје од 1970. године до краја осамдесетих година карактеристична је била већа усмереност педагошке науке на емпиријска проучавања ових проблема. У Београду је 1982. године организован симпозијум о васпитној улози породице. Укључивање других научних дисциплина (социологије, психологије, права, медицине) у проучавање овог проблема требало је да допринесе свеобухватнијем сагледавању породице и односа у њој. Данас је веома изражен интердисциплинарни приступ у проучавању породице и њене васпитне улоге.

И четврти период, по нашем мишљењу, започиње око 1990. године и траје до данас. Почетак адекватнијег развоја Породичне педагогије поклапа са укидањем социјалистичких друштвених односа, на овим просторима, што нам опет указује на значај душтвене условљености. У овом периоду педагошка наука заиста почиње да даје адекватан допринос у проучавању васпитања у породици. Многи аутори се на један веома озбиљан начин баве овим питањима, а такође, у овом пероиду, Породична педагогија, на катедри за педагогију почиње да се предаје као посебан предмет, што такође говори о промењеној позицији ове области у систему педагошких дисциплина.

Иако је интердисциплинарни приступ у проучавању породице неопходан, педагогија као наука треба да заузме значајније место у проучавању проблема који се односе на родитељске улоге и поцес васпитања у породици. За адекватније укључивање педагошке науке у проучавање проблема васпитања у породици, важно је сагледати какву позицију Породична педагогија има у студијским програмима педагогије на филозофским факултетима код нас и у окружењу. 


\section{2. Методолошки оквир истраживања}

Истраживање је спроведено у намери да испитамо како је област породичне педагогије на студијама педагогије присутна и позиционирана на филозофским факултетима у Србији и окружењу. Предмет нашег истраживања био је да сагледамо и утврдимо начин на који је студијски предмет Породична педагогија заступљен на филозофским факултетима у нашој земљи и земљама у окружењу. Узели смо у обзир да се садржаји породичне педагогије могу наћи и под неким другим именом. Циљ истраживања је анализирање позиције предмета из области породичне педагогије на нивоу основних академских студија филозофских факултета у Србији и окружењу. Коришћена је метода теоријске и компаративне анализе, а од техника - анализа садржаја доступних програмских докумената и силабуса. Основне јединице анализе су: студијски програм, година студија и семестар, назив предмета, статус предмета и број ESPB кредита. Основна хипотеза истраживања јесте да су на свим проучаваним филозофским факултетима присутни садржаји из области породичне педагогије са позицијом обавезних предмета у студијским програмима педагогије. Узорак истраживања чинили су програмска документација и силабуси филозофских факултета у Србији, Републици Српској, Босни и Херцеговини, Хрватској, Црној Гори и Македонији. Намера нам је да овом анализом потврдимо и укажемо на могућност уношења одређених промена у начину реализације, броју ESPB кредита, евентуално преименовање, ширење и унапређивање предмета из области породичне педагогије.

\section{3. Компаративни приказ анализе основних јединица проучавања студијских програма}

\section{1. Породична педагогија као студијски предмет на филозофским факултетима у Србији}

Компаративном анализом студијских програма на филозофским факултетима у Србији стичемо увид о заступљености и позицији породичне педагогије у структури студијских програма.

Табела 1. Табеларни приказ јединица анализе филозофских факултета у Србији

\begin{tabular}{|l|c|c|c|c|c|}
\hline \multicolumn{1}{|c|}{$\begin{array}{c}\text { Високошколска } \\
\text { установа }\end{array}$} & $\begin{array}{c}\text { Студијски } \\
\text { програм }\end{array}$ & $\begin{array}{c}\text { Година } \\
\text { студија, } \\
\text { семестар }\end{array}$ & Назив предмета & $\begin{array}{c}\text { Статус } \\
\text { предмета }\end{array}$ & ESPB \\
\hline $\begin{array}{l}\text { 1. Филозофски } \\
\text { факултет у Београду }\end{array}$ & Педагогија & $\begin{array}{c}\text { IV година, } \\
\text { VII семестар }\end{array}$ & Породична педагогија & О & 5 \\
\hline $\begin{array}{l}\text { 2. Филозофски } \\
\text { факултет у Новом } \\
\text { Саду }\end{array}$ & Педагогија & $\begin{array}{c}\text { I година, } \\
\text { I II семестар; } \\
\text { IV година, } \\
\text { VIII семестар }\end{array}$ & $\begin{array}{c}\text { Породична педагогија } \\
\text { 1 и 2; } \\
\text { Савремено родитељство }\end{array}$ & $\begin{array}{c}\text { О } \\
\text { И }\end{array}$ & 5 \\
\hline
\end{tabular}




\begin{tabular}{|l|c|c|c|c|c|}
\hline $\begin{array}{l}\text { 3. Филозофски } \\
\text { факултет у Косовској } \\
\text { Митровици }\end{array}$ & Педагогија & $\begin{array}{c}\text { II година, } \\
\text { III семестар }\end{array}$ & Породична педагогија & O & 6 \\
\hline \multirow{2}{*}{$\begin{array}{l}\text { 4. Филозофски } \\
\text { факултет у Нишу }\end{array}$} & Педагогија & $\begin{array}{c}\text { III година, } \\
\text { VI семестар; } \\
\text { IV година, } \\
\text { VIII семестар }\end{array}$ & $\begin{array}{c}\text { Породична педагогија; } \\
\text { Педагогија родитељства }\end{array}$ & O & 6 \\
\hline
\end{tabular}

У Табели 1 јасно се види да се на свим филозофским факултетима у оквиру студијских програма педагогије, реализују курсеви из области породичне педагогије. На свим факултетима постоји макар један предмет под називом Породична педагогија који је обавезан по статусу. Поред Породичне педагогије, на Филозофском факултету у Нишу реализује се и курс под називом Педагогија родитељства, који је такође обавезан, а на Филозофском факултету у Новом Саду, осим што се Породична педагогија изучава у два семестра, као Породична педагогија I и II реализује се и курс под називом Савремено родитељство као изборни предмет. Разлика је очигледна у односу на годину студија на којој се овај предмет изучава, с обзиром да присутност предмета варира од прве до четврте године на свим факултетима. Ово се може тумачити разликом у принципима по којим је извршена расподела предмета по семестрима. Тако се на факултетима на којима је породична педагогија на завршним годинама студија, вероватно пошло од идеје да је за изучавање и разумевање ових садржаја неопходна одређена зрелост у размишљању, као и да су ови садржаји прихватљивији када студенти, односно адолесценти мање у фази дистанцирања од родитеља, а самим тим и више заинтересовани за проучавање проблема породичног васпитања. Ипак, на неким факултетим Породична педагогија је смештена на почетку студија по логици изучавања најпре предмета који су везани за рано васпитање (и васпитање у породици), преко предмета који се односе на васпитање и образовање у предшколским и школским институцијама, па до образовања одраслих, односно, према узрасту васпитаника.

Када се погледа број кредита и оптерећеност судената, може се видети да је присутна уједначеност јер је на свим студијским програмима породична педагогија заступљена са 5 односно 6 ESPB кредита, што значи да је Породична педагогија врло високо позиционирана у односу на остале предмете на студијском програму педагогије.

Такође постоји одређена подударност у односу на теоријски приступ у сагледавању садржаја породичне педагогије, што је утврђено упоређивањем садржаја који се налазе у силабусима предмета. Дилема коју је изнео Педичек (Pediček, 1982), у односу на социјални или индивидуални приступ у проучавању проблема породичног васпитања, превазиђена је захваљујући системском приступу, који је присутан у свим силабусима породичне педагогије, и који је успешно коришћен у сагледавању породице и породичних односа. 


\section{2. Породична педагогија као студијски предмет на филозофским факултетима у земьама у окружену}

У жељи да утврдимо место породичне педагогије у педагогији као науци, налазимо да је неопходно извршити анализу студијских програма педагогије на филозофским факултетима у земљама у окружењу. Са тим циљем, у овом раду смо се бавили анализом студијских прорама филозофских факултета у Републици Српској, Босни и Херцеговини, Хрватској, Црној Гори и Македонији. Користили смо исте јединице анализе као и код компаративног приказа студијских програма у Србији (студијски програм, година студија и семестар, назив предмета, статус предмета и ESPB бодова/кредита). Иако је анализа земаља у окружењу приказана у једној табели, детаљнија анализа је извршена у наставку за сваку државу појединачно. Компаративном анализом суседних земаља желимо указати на значај изучавања породичне педагогије кроз њену приметну присутност и статус обавезног предмета на факултетима у окружењу. Компарацијом ових јединица анализе утврђујемо које је место и који је статус Породичне педагогије у педагошкој науци у Србији. Истовремено, анализом је могуће увидети и неке другачије облике организације предмета, почевши од семестра у коме се реализује предмет, па до броја ESPB бодова/кредита. Овим указујемо на могуће импликације приликом иновирања и импементације нових педагошких стремљења на филозофским факултетима у Србији.

Табела 2. Табеларни приказ јединица анализе филозофских факултета у окружењу

\begin{tabular}{|c|c|c|c|c|c|}
\hline $\begin{array}{c}\text { Високошколска } \\
\text { установа }\end{array}$ & $\begin{array}{c}\text { Студијски } \\
\text { програм } \\
\end{array}$ & \begin{tabular}{|c|}
$\begin{array}{c}\text { Година студија, } \\
\text { семестар }\end{array}$ \\
\end{tabular} & Назив предмета & $\begin{array}{c}\text { Статус } \\
\text { предмета } \\
\end{array}$ & ESPB \\
\hline $\begin{array}{l}\text { 1. Филозофски } \\
\text { факултет у Бања } \\
\text { Луци }\end{array}$ & Педагогија & $\begin{array}{l}\text { II година, } \\
\text { III семестар }\end{array}$ & Породична педагогија & $\mathrm{O}$ & 4 \\
\hline $\begin{array}{l}\text { 2. Филозофски } \\
\text { факултет у } \\
\text { Источном Сарајеву }\end{array}$ & Педагогија & $\begin{array}{l}\text { I година, } \\
\text { II семестар }\end{array}$ & Породична педагогија & $\mathrm{O}$ & 5 \\
\hline $\begin{array}{l}\text { 3. Филозофски } \\
\text { факултет у Сарајеву }\end{array}$ & Педагогија & $\begin{array}{l}\text { I година, } \\
\text { I семестар; } \\
\text { I година, } \\
\text { II семестар }\end{array}$ & $\begin{array}{c}\text { Основи обитељске } \\
\text { педагогије; } \\
\text { Интраобитељска } \\
\text { динамика } \\
\end{array}$ & $\begin{array}{l}\mathrm{O} \\
\mathrm{O}\end{array}$ & $\begin{array}{l}5 \\
6\end{array}$ \\
\hline $\begin{array}{l}\text { 4. Филозофски } \\
\text { факултет у Тузли }\end{array}$ & Педагогија & $\begin{array}{l}\text { II година, } \\
\text { III семестар; } \\
\text { II година, } \\
\text { IV семестар } \\
\end{array}$ & $\begin{array}{l}\text { Породична педагогија I; } \\
\text { Породична педагогија II }\end{array}$ & $\begin{array}{l}\mathrm{O} \\
\mathrm{O}\end{array}$ & $\begin{array}{l}6 \\
6\end{array}$ \\
\hline $\begin{array}{l}\text { 5. Филозофски } \\
\text { факултет у Осјеку }\end{array}$ & Педагогија & $\begin{array}{l}\text { II година, } \\
\text { III семестар }\end{array}$ & Обитељска педагогија & $\mathrm{O}$ & 4 \\
\hline $\begin{array}{l}\text { 6. Филозофски } \\
\text { факултет у Ријеци }\end{array}$ & Педагогија & $\begin{array}{l}\text { II година, } \\
\text { III семестар }\end{array}$ & Обитељска педагогија & $\mathrm{O}$ & 5 \\
\hline $\begin{array}{l}\text { 7. Филозофски } \\
\text { факултет у Загребу }\end{array}$ & Педагогија & $\begin{array}{l}\text { I година, } \\
\text { II семестар }\end{array}$ & Обитељска педагогија & $\mathrm{O}$ & 5 \\
\hline
\end{tabular}




\begin{tabular}{|l|c|c|c|c|c|}
\hline $\begin{array}{l}\text { 8. Филозофски } \\
\text { факултет у } \\
\text { Никшићу }\end{array}$ & Педагогија & $\begin{array}{c}\text { I година, } \\
\text { II семестар }\end{array}$ & Породична педагогија & O & 7 \\
\hline $\begin{array}{l}\text { 9. Филозофски } \\
\text { факултет у Скопљу }\end{array}$ & Педагогија & $\begin{array}{c}\text { II година, } \\
\text { III семестар }\end{array}$ & Породична педагогија & O & 5 \\
\hline
\end{tabular}

Из Табеле 2 можемо видети да се на студијским програмима педагогије у Републици Српској (Филозофски факултет у Бања Луци и Филозофски факултет у Источном Сарајеву) изучавају предмети под називом Породична педагогија као једносеместрални. Ови предмети су по статусу обавезни и реализују се на почетку студија, у првој (у Источном Сарајеву), односно другој години студија (у Бања Луци).

У Босни и Херцеговини на студијским програмима педагогије изучавају се предмети различитих назива, на Филозофском факултету у Сарајеву то су: Основи обитељске педагогије и Интраобитељска динамика, док је на Филозофском факултету у Тузли присутна класична подела двосеместралног предмета на два дела: Породична педагогија I и Породична педагогија II. Наведени предмети су по статусу обавезни и такође се изучавају на почетку студија, у првој (у Сарајеву), односно у другој години (у Тузли).

Што се тиче Хрватске, из табеле се јасно види да се ради о предметима под истим називом: Обитељска педагогија. На свим факултетима су једносеместрални и по статусу обавезни, а реализују се у другој години (на Филозофском факултету у Осијеку и на Филозофском факултету у Ријеци), односно у првој (на Филозофском факултету у Загребу).

У Црној гори, на Филозофском факултету у Никшићу, Породична педагогија се изучава као обавезни једносеместрални предмет, а овде је нарочито приметан висок број ESPB бројева (7, за разлику од осталих факултета где се број креће око 5 у просеку). Предмет се реализује у првој години.

На крају Табеле 2 видимо да се на студијском програму педагогије у Македонији (Филозофски факултет у Скопљу) Породична (Семејна) педагогија изучава као једносеместрални и обавезни предмет. Реализује се на другој години студија.

Ако погледамо структуру наведених студијских програма, очигледно је да су у првим годинама студија предвиђени предмети који развијају опште педагошке компетенције, да би предмети постепено имали све снажнији нагласак на специфичне компетенције професије (ово је нарочито видљиво на Филозофском факултету у Ријеци). Такође, на појединим програмима Породична педагогија је смештена на почетку студија по логици изучавања најпре предмета који су везани за рано васпитање (и васпитање у породици), преко предмета који се односе на васпитање и образовање у предшколским и школским институцијама, па до образовања одраслих (ово је нарочито приметно на филозофским факултетима у Босни), односно може се рећи да је у питању подела према узрасту васпитаника.

На крају анализе требало би продискутовати и о најмањој усаглашености на факултетима у односу на све јединице анализе, а то су ESPB бројеви. Нај- 
мањи број ESPB кредита предмет Породична педагогија има у студијским програмима педагогије Факултета у Осјеку и Факултета у Бања Луци, а највећи број ESPB кредита код овог предмета налазимо на Факултету у Никшићу. У осталим студијским програмима број ESPB кредита не варира много односно у неким програмима носи 5 у некима 6 ESPB кредита. Наведена неусаглашеност се може тумачити различитим принципима расподеле броја ESPB кредита, али и значајношћу која се придаје изучавању проблема Породичне педагогије. Наиме, уочено је да је у студијском програму педагогије на Факултету у Никшићу расподела ESPB кредита извршена тако да предмети који су уже стручно педагошки имају већи број ESPB кредита (међу њима и Породична педагогија), док општи предмети и изборни предмети имају знатно мањи број ESPB кредита. Сличан принцип расподеле примећује се и на Факултету у Осјеку, с тим да је тамо врло видљива разлика у вредновању предмета, те се у случају департмана за педагогију предмети вреднују од 1 до 5, те се Породична педагогија вреднује ca 4. У сваком случају, може се закључити да је предмет Породична педагогија доста високо позициониран у систему вредновања предмета у студијским програмима педагогије

\section{Закључак}

У раду смо истакли мисли наших познатих педагога о проблемима васпитања у породици с краја XIX и почетка XX века. Проблемима васпитања у породици на факултетима приступало се најпре из угла других, тада развијенијих наука. У последњој деценији XX века педагошка наука почиње да даје адекватан допринос у проучавању васпитања у породици. Породична педагогија као предмет у оквиру студијских програма педагогије присутна је тек неколико деценија, најпре се појављује као изборни предмет, а тек почетком XXI Породична педагогија је сврстана у групу обавезних предмета.

Иако је интердисциплинарни приступ у проучавању породице неопходан, ипак педагогија као наука треба да заузме значајније место у проучавању проблема који се односе на родитељске улоге и поцес васпитања у породици. Како би се педагошка наука адекватније укључила у проучавање проблема васпитања у породици, важно је сагледати какву позицију породична педагогија има у студијским програмима педагогије на филозофским факултетима код нас и у окружењу.

Подаци које смо изнели у раду потврдили су постављену хипотезу од које смо пошли - да су на свим проучаваним филозофским факултетима присутни садржаји из области породичне педагогије, притом свуда у статусу обавезних предмета у студијским програмима педагогије. Сличности се јављају у готово свим јединицама анализе, од студијског програма, преко назива предмета, статуса предмета до броја ESPB кредита. Наиме, у готово свим анализираним студијским програмима налазимо макар један обавезни предмет под називом Породична педагогија. Ипак, углавном је у питању заправо само један предмет 
из области Породичне педагогије. Једино на студијским програмима педагогије факултета у Сарајеву, у Тузли и у Новом Саду затичемо по два обавезна предмета из области породичне педагогије као на Факултету у Нишу. Разлике се примећују нарочито у години и семестру у коме се слуша што је била једна од јединице анализе. Док се на Факултету у Нишу курс из области породичне педагогије реализује у трећој и четвртој години, на осталим факултетима, нарочито у окружењу, овај курс се реализује знатно раније, у првој, односно другој години студирања, вероватно по логици изучавања предмета распоређених према узрасту васпитаника. Најнижи степен усаглашености уочава се када је број ESPB кредита у питању, реч је о распону од 4 до 7 ESPB кредита, што се може тумачити различитим принципима расподеле броја ESPB кредита, али и значајношћу која се придаје изучавању проблема породичне педагогије. У сваком случају, примећено је да је Породична педагогија високо позиционирана у систему вредновања предмета на студијским програмима педагогије у нашој земљи и у окружењу. Такође постоји одређена подударност у односу на теоријски приступ у сагледавању садржаја породичне педагогије, а то је системски приступ, који је присутан у силабусима Породичне педагогије, у сагледавању породичних односа, родитељских улога и разумевању проблема васпитања у породици.

Овим истраживањем смо желели да сагледамо позиционираност предмета Породична педагогија у студијским програмима педагогије код нас, и у окружењу, као и да укажемо на потребу иновирања и унапређивања овог курса на студијским програмима педагогије.

\section{Литература}

Bakić, V. (1901). Posebna pedagogika. Beograd: Državna štamparija.

Krneta, Lj., Potkonjak, M., Potkonjak, N. (1965). Pedagogija. Beograd: Zavod za izdavanje udžbenika Republike Srbije.

Milošević, N. (1999). Porodično vaspitanje u delima srpskih pedagoga s kraja XIX i početka XX veka. Nastava i vaspitanje, 3-4.

Miodragović, J. (1914). Narodna pedagogija u Srba ili kako naš narod podiže porod svoj. Beograd: Izdanje zadužbine Ilije M. Kolarca.

Mladenović, V. (1922). Osnovi nauke o vaspitanju, Beograd.

Pataki, S. (1950). Opća pedagogija. Zagreb: Pedagoško književni zbor.

Pediček, F. (1982). Porodično vaspitanje u svetlu današnje teorije vaspitanja, Zbornik, 15.

Stanojlović, B. (1992). Porodica i vaspitanje dece. Beograd: Naučna knjiga.

Tešić, V. (1981). Vićentije Rakić - Ličnost, rad, pedagoške ideje. Beograd.

\section{Извори са Интернет мреже:}

https://drive.google.com/file/d/1yYSHkYsKTcd0Hj0E7ewRJvTejxmt9Ues/view 
https://docs.google.com/document/d/1A3MJ4PYYjhm2u5ZqJtTufomGTieBOQP59iYC YxNIZOk/edit

https://drive.google.com/file/d/0BzVmKuYYMVVqU0NfXzA2T2FmaXM/view

http://ff.ues.rs.ba/index.php/s-udi-s-i-pr-gr-i/prvi-ci-lus/p-d-g-gi

https://ff.unibl.org/i-ciklus-nastavni-plan/pedagogija

http://ff.unsa.ba/files/trajno/npp_2019/NPP-Pedagogija-2019-2020.pdf

https://www.ffri.uniri.hr/files/studijskiprogrami/2018-2019/PED_1P-program_ preddipl-2018_2019.pdf

https://sokrat.ffos.hr/ff-info/studiji.php?action=show\&id=9

http://theta.ffzg.hr/ECTS/Studij/Index/931

http://www.f.bg.ac.rs/pedagogija/program_studija.php?god $=4 \&$ nivo $=0$

http://www.ff.uns.ac.rs/uploads/files/Studijski\%20programi/2015/OAS/Pedagogija\%20 OAS\%202015.pdf

https://www.ucg.ac.me/studprog/3/15/1/2019-pedagogija-2017

http://www.untz.ba/uploads/file/nastava/studijski_prog_I_ciklusa/2018-19/FF_ Pedagogija_studijski_program_I_ciklus_2018_19.pdf

\title{
COMPARATIVE ANALYSIS OF FAMILY PEDAGOGY COURSES IN STUDY PROGRAMS OF FACULTIES OF PHILOSOPHY IN SERBIA AND NEIGHBORING COUNTRIES
}

\author{
Marina Matejević, Marija Đorđević \\ University of Niš, Faculty of Philosophy, Department of Pedagogy
}

\begin{abstract}
Family pedagogy as a subject area within the study programs of pedagogy has been introduced in the last decade of the twentieth century as an elective course. From the beginning of the $21^{\text {st }}$ century family pedagogy has been subsequently classified as a required course. The paper presents the development of family pedagogy in our country. The research was conducted in order to examine how the field of family pedagogy in pedagogy studies was represented at the faculties of philosophy in Serbia and the neighboring countries. The content analysis was used as a basic research technique for the analysis of available program documents and syllabuses. The basic units of analysis were: study programs, years of study and semesters, course names, course status in the programs and numbers of ECTS points. The results of the comparative analysis show that all the examined faculties of philosophy have contents in the field of family pedagogy in terms of required, core courses in the study programs of pedagogy. There are differences regarding the year and semester as well as the number of ECTS points. With the analysis we tried to point out the possibility of making certain changes
\end{abstract}


in the way of realization, first of all in the number of ECTS points, but also the possible expansion and improvement of courses in the field of family pedagogy.

Key words: family pedagogy, study program, course name, course status

\section{Citiranje članka:}

Matejević, M. i Đorđević, M. (2019). Komparativna analiza porodične pedagogije u studijskim programima pedagogije Filozofskih fakulteta u Srbiji i okruženju. Godišnjak za pedagogiju, 4(2), 7-19 